\title{
FGL2 Gene
}

National Cancer Institute

\section{Source}

National Cancer Institute. FGL2 Gene. NCI Thesaurus. Code C131280.

This gene may be involved in memory $\mathrm{T}$-cell function. 